\title{
The Constitutional Status of Karlsruhe's Novel "Jurisdiction" in EU Fundamental Rights Matters: Self-inflicted Institutional Vulnerabilities
}

\author{
Karsten Schneider
}

(Received 24 February 2020; accepted 24 February 2020)

\begin{abstract}
The First Senate of the German Federal Constitutional Court (FCC) has recently introduced the express promise that where EU fundamental rights take precedence over German fundamental rights, the Court itself could directly review, on the basis of EU fundamental rights, the application of EU law by German authorities. There are, however, differences between the Basic Law as the relevant standard of review and other standards of review that are dangerous to ignore. The constitutional status of the FCC's jurisdiction depends crucially on whether the Court relies on the constitution or on EU fundamental rights. If the constitutional status of the novel jurisdiction covered any binding-effect, and that is a big if, the FCC still would not safeguard the unity and coherence of Union law. Leaving aside the fact that the First Senate is confined to reversing and remanding (unable to enforce anything directly), no beneficial effect on legal certainty grows apparent. Any binding-effect of the novel jurisdiction only provides for consistency without finality. And to venture further into the question: Even if anyone welcomed this novel kind of consistency without finality (virtually "provisional consistency"), this oddish consistency would still be a localized consistency, i.e. in German courts only.
\end{abstract}

Keywords: Right to be forgotten; Federal Constitutional Court; EU Fundamental Rights; binding effects; legal certainty

The First Senate of the German Federal Constitutional Court (FCC) has recently introduced the express promise that where EU fundamental rights take precedence over German fundamental rights, the Court itself could directly review, on the basis of EU fundamental rights, the application of EU law by German authorities. ${ }^{1}$ This newly invented idea - Karlsruhe's ${ }^{2}$ novel "jurisdiction"3 renounces one of the most distinctive, if sometimes controversial, principles in the FCC's institutional history: In cases where the Court found the fundamental rights of the Basic Law to be inapplicable due to the precedence of EU law, it completely refrained from conducting a review

${ }^{\star}$ Professor of Public Law, International Law, Legal Theory, University of Mainz.

${ }^{1}$ BVerfG, Nov. 6, 2019, docket number 1 BvR 276/17 - Right to be forgotten II.

${ }^{2}$ One Chamber of the Second Senate has already made cautious reference to the new case law of the First Senate, see BVerfG (Chamber), Jan. 30, 2020, docket number 2 BvR 1005/18, juris, para. 32 (with regard to BVerfG, Nov. 6, 2019, docket number 1 BvR 16/13 - Right to be forgotten I).

${ }^{3}$ The First Senate labels this newly invented competence as a "jurisdiction" (Jurisdiktion), see BVerfG, Nov. 6, 2019, docket number 1 BvR 276/17 - Right to be forgotten II, para. 32. It is important to distinguish carefully between this abstract competence ("jurisdiction"), future decisions exercising this jurisdiction and the present case (Right to be forgotten II) inventing this jurisdiction.

(C) The Author(s) 2020. Published by Cambridge University Press on behalf of the German Law Journal. This is an Open Access article, distributed under the terms of the Creative Commons Attribution licence (http://creativecommons.org/licenses/by/4.0/), which permits unrestricted re-use, distribution, and reproduction in any medium, provided the original work is properly cited. 
of fundamental rights violations, ${ }^{4}$ discarding in particular the possibility of directly invoking EU fundamental rights in its review. ${ }^{5}$ Two decades after the solemn proclamation of the EU's Charter of Fundamental Rights, this principle has gained in pertinence as legal provisions that are fully harmonized under EU law proliferate and scenarios become abundant where EU law takes precedence of application over the fundamental rights of the Basic Law. Concern has spread, while the potential persists for gaps in fundamental rights protection, for loss of institutional significance and for lost options at the strategic level with regard to an even closer cooperation with the Court of Justice of the European Union (CJEU).

There is no doubt that resilient mechanisms of judicial cooperation have become important constitutional requirements, which provide much-needed legal certainty. Examples include transparent criteria for taking into account decisions of the European Court of Human Rights (ECtHR), ${ }^{6}$ or providing predictable procedures for ultra-vires-reviews, including the requirement of a preliminary reference before finding an act of the EU to be ultra vires. ${ }^{7}$ There are, however, differences between the Basic Law as the relevant standard of review and other standards of review that are dangerous to ignore. The constitutional status of the FCC's jurisdiction depends crucially on whether the Court relies on the constitution or on EU fundamental rights. However, it bears mentioning that the First Senate remained stone silent on matters of constitutional status.

\section{A. The $800 \mathrm{lb}$. Gorilla in the Room}

The constitutional status of the FCC's novel jurisdiction addresses a legal concept. It comprises answers to questions based on status like: "Is there a binding effect of a decision of the FCC?", "Does the binding effect possibly extend to all state bodies and in principle impose on these an obligation to create a situation that complies with the FCC's jurisdiction?", "Do German courts have to observe and apply EU fundamental rights within the limits set by the FCC's novel jurisdiction?" and "May a complainant challenge the disregard of this potential duty of consideration or compliance as a violation of the fundamental right whose area of protection is affected or as a violation of the principle of the rule of law - or must she not challenge a disregard at all?". 8

Obviously, these constitutional status related aspects of the novel jurisdiction stand in sharp contrast to psychological angles (such as: "Do we appreciate cooperating courts?" or "Is there a reason to believe that the CJEU might object to this new line of jurisprudence?"), to the behavioral

\footnotetext{
${ }^{4}$ BVerfG, Dec. 17, 1953, docket number 1 BvR 147/52, 3 BVerfGE 58, 74; BVerfG, May 7, 1957, docket number 2 BvR 2/56, 6 BVERFGE 376, 385; BVerfG, Jan. 14, 1960, docket number 2 BvR 243/60, 10 BVERFGE 271, 274 - “judicial protection is not measured according to the European Convention on Human Rights"; BVerfG, May 29, 1974, docket number 2 BvL 52/71, 37 BVERFGE 271, 283 - "judicial protection by the Federal Constitutional Court is measured exclusively according to the constitutional law of the Federal Republic of Germany and according to the more precise rules laid down in the Federal Constitutional Court Act"; BVerfG, Dec. 17, 1975, docket number 1 BvR 548/68, 41 BVerfGE 88, 106; BVerfG, Mar. 2, 1993, docket number 1 BvR 1213/85, 88 BVERFGE 87, 112 - "judicial protection is not measured according to the European Social Charta ... The Federal Constitutional Court does not review any domestic application of legislation on the basis of EU law"; BVerfG, Mar. 16, 2004, docket number 1 BvR 1778/01, 110 BVERFGE 141, 154 seq. - "no constitutional complaints on the basis of EU law"; BVerfG (Chamber), Jun. 27, 2014, docket number 1 BvR 1313/14, juris, para. 7. This established case law, however, had not been truly noticed recently, when the First Senate optimistically stressed: "In its past decisions, the Federal Constitutional Court has not yet expressly considered the possibility of directly invoking EU fundamental rights in its review.", see BVerfG, Press Release No. 84/2019, Nov. 27, 2019, https://www.bundesverfassungsgericht.de/ SharedDocs/Pressemitteilungen/EN/2019/bvg19-084.html, para. 3a.

${ }^{5}$ FrANK SCHORKopf, STAATSRECHT DER INTERNATIONALEN BEZIEHUNGEN $₫ 8$ para. 92 (2017).

${ }^{6}$ See BVerfG, Oct. 14, 2004, docket number 2 BvR 1481/04, 111 BVERFGE 307 - Görgülü.

${ }^{7}$ See BVerfG, Jul. 6, 2010, docket number 2 BvR 2661/06, 126 BVerfGE 286 - Honeywell; Karsten Schneider, Der Ultravires-Maßstab im Außenverfassungsrecht: Skizze sicherer Vollzugszeitumgebungen für zwischenstaatliche und supranationale Integrationsprozesse, 139 Archiv des öffentlichen Rechts 196-256 (2014).

${ }^{8}$ BVerfG, Jun. 10, 1975, docket number 2 BvR 1018/74, 40 BVERfGE 88, 94; BVerfG, Jan. 18, 2006, docket number 2 BvR 2194/99, 115 BVERFGE 97, 108; with regard to the constitutional status of decisions of the European Court of Human Rights (ECtHR), see BVerfG, Oct. 14, 2004, docket number 2 BvR 1481/04, 111 BVERFGE 307 - Görgülü.
} 
motivation ("Why did the Justices invent this novel jurisdiction?") and to the underlying rationale ("What is the Court's statement of reasons?").

Not only against the backdrop of the last-mentioned aspects, the constitutional status of the novel jurisdiction is assumed to be the preliminary question. Also, from the claimant's perspective and with a view to the authorities and courts of the Federal Republic of Germany the constitutional status matters, especially mode and manner of potentially binding effects.

The First Senate, however, has delivered the two orders establishing the novel jurisdiction without wasting any word on the constitutional status of the novel jurisdiction. ${ }^{9}$ This deafening silence appears even the more surprising, considering the procedural mechanics of constitutional complaints within the German legal order and judicial system: Constitutional complaints generally enable individuals to assert their freedoms guaranteed under the Constitution - and now that we know: under EU fundamental rights, too - vis-à-vis the state. In both cases, a constitutional complaint is not exactly part of the avenue of appeal from regular courts, but an extraordinary remedy in the course of which the FCC only examines whether specific constitutional law - and now that we know: specific constitutional law or EU fundamental rights - were violated..$^{10}$ More to the point, it is always for the regular courts to render any subsequent decisions as may be necessary for affording protection of the individual. To put it another way, the FCC neither alters nor changes unconstitutional court decisions. Karlsruhe may merely reverse an unconstitutional court decision and remand the matter to a competent court, Section 95 of the Federal Constitutional Court Act (FCCA). ${ }^{11}$ That renders the legal status of the novel jurisdiction relevant: What if that competent court does not agree with Karlsruhe?

\section{B. The Old World}

With regard to plain old constitutional complaints (i.e. the applicable Basic Law as the relevant standard of review), Section 31 (1) FCCA lays the legal effects of FCC decisions down in abundant clarity: Decisions of the FCC shall be binding upon the constitutional organs of the Federation and of the Laender, as well as on all courts and those with public authority. ${ }^{12}$

\section{Taking Binding Effects Seriously?}

Whether the same applies to the novel jurisdiction is questionable - and the FCC has not yet shared a fleeting glimpse of the constitutional status. But what exactly are the reasons, why is it that the novel jurisdiction cannot automatically be assumed to be binding upon the constitutional organs of the Federation and of the Länder, as well as on all courts and those with public authority? ${ }^{13}$

Two examples suggest the kind of legal questions the First Senate inclines towards answering in the future, based on the novel jurisdiction: First, the Court held that "the fundamental rights of the

\footnotetext{
${ }^{9}$ This is surprising, the two orders (BVerfG, Nov. 6, 2019, docket number 1 BvR 16/13 - Right to be forgotten I; BVerfG, Nov. 6, 2019, docket number 1 BvR 276/17 - Right to be forgotten II) are a mass of text, comprising about 34.000 words.

${ }^{10}$ See Art. 93 (1) no. 4a of the Basic Law and $\$ \$ 90$ et seq. of the Federal Constitutional Court Act (FCCA); BVerfG, Jan. 27 , 1965, docket number 1 BvR 66/60, 18 BVERFGE 315, 325; BVerfG, Oct. 9, 2002, docket number 1 BvR 1611/96, 106 BVERFGE 28,45 .

${ }^{11}$ BVerfG, Jan. 25, 1961, docket number 1 BvR 9/57, 12 BVERFGE 113, 132; BVerfG, Jun. 5, 1973, docket number 1 BvR 536/ 72, 35 BVERFGE 202, 244 et seq. (differentiating with regard to provisional orders).

${ }^{12}$ BVerfG, Jun. 10, 1975, docket number 2 BvR 1018/74, 40 BVERFGE 88 (94); BVerfG, Feb. 28, 1989, docket number 1 BvR 1291/85, 79 BVERfGE 365, 368; BVerfG, Jan. 18, 2006, docket number 2 BvR 2194/99, 115 BVERFGE 97, 108; BVerfG (Chamber), Dec. 15, 2004, docket number 1 BvR 2495/04, juris, para. 11; Andreas Heusch, $\mathfrak{S} 31$, in BundeSVERFASSUNGSGERICHTSGESETZ paras. 20 et seq. (Christian Burkiczak, Franz-Wilhelm Dollinger \& Frank Schorkopf eds. 2015); Eckart Klein, $\$$ 40, in Verfassungsprozessrecht (Ernst Benda, Eckart Klein \& Oliver Klein eds., 3rd ed. 2011).

${ }^{13} \S 31(1)$ FCCA.
} 
EU Charter are not limited to protecting citizens vis-à-vis the state, but also afford protection in disputes under private law"; ${ }^{14}$ and second, the Court established that a "search engine operator cannot invoke the right to freedom of expression under Art. 11 of the Charter in relation to the search results disseminated by its search engine." 15 In respect of each example, the vague constitutional status of the novel jurisdiction has not created imminent problems for the simple reason that the constitutional complaint was unsuccessful on the merits (i.e. the First Senate did not reverse an unconstitutional court decision).

If, however, those novel decisions were binding upon all German courts like any conventional decision in the past, the novel jurisdiction would - most likely - be incompatible with the precedence of application accorded to EU fundamental rights. Moreover, the novel jurisdiction would - taking the binding effect seriously - undermine the option to refer relevant questions of interpretation for a preliminary ruling pursuant to Art. 267 (3) of the Treaty on the Functioning of the European Union (TFEU). The First Senate has, as mentioned earlier, not yet touched upon the question whether the novel decisions are binding. And it may seem absurd to hypothesize a German court being obliged to observe and apply EU fundamental rights within the limits set by the FCC's novel jurisdiction. The very idea of versioning - i.e. distinguishing between a European version of EU fundamental rights and some kind of Karlsruhe version of EU fundamental rights - runs contrary to safeguarding the unity and coherence of Union law (and therefore contrary to case law ${ }^{16}$ of the Second Senate). ${ }^{17}$ Thus it appears that the novel jurisdiction would not be binding upon all German courts.

The alternative of the First Senate developing and maintaining a novel jurisdiction beyond Section 31 (1) FCCA without binding effects, however, is likely not to be palatable to the institution $^{18}$ as Federal Constitutional Court except under the most unlikely lead scenario of enduring consensus among the FCC, CJEU and all German Courts, and even then it may not be feasible: Karlsruhe would reverse an unconstitutional court decision and remand the matter to a competent court. In case of non-binding remand court procedures, the competent court could simply repeat the reversed decision - this would render the novel jurisdiction useless. ${ }^{19}$ Or the competent court could refer the exact question for a preliminary ruling pursuant to Art. 267 (3) TFEU - exposing the FCC. Constitutional principles justifying constitutional complaints with the non-binding option of repeating reversed decisions are difficult to imagine. The same is true of the First Senate, delivering on the promise to "ensure that there are no gaps in fundamental rights protection". Let alone the institutional damage for the FCC: non-binding decisions - easily ignored by lower courts and without limitations corrected by the CJEU's preliminary rulings pursuant to Art. 267 (3) TFEU - could eventually garner public attention, with claimants demanding more effective remedies and lower courts requiring certainty of the law.

\section{Divide and Conquer the Undividable?}

The First Senate presumably senses at least some of these imminent complications. Accordingly, a cavalier clarification has a focus on some new kind of the notorious "close cooperation with the

\footnotetext{
${ }^{14}$ BVerfG, Nov. 6, 2019, docket number 1 BvR 276/17 - Right to be forgotten II, para. 96.

${ }^{15}$ BVerfG, Nov. 6, 2019, docket number 1 BvR 276/17 - Right to be forgotten II, para. 105.

${ }^{16}$ See BVerfG, Jun. 30, 2009, docket number 2 BvR 1010/08, 123 BVERFGE 267, 354 - Lissabon; BVerfG, Jul. 6, 2010, docket number 2 BvR 2661/06, 126 BVERFGE 286, 302-303 - Honeywell.

${ }^{17}$ See Article 19 (1) sentence 2 TEU and Article 267 TFEU; SCHORKopf, supra note 5, at $\$ 8$ para. 172.

${ }^{18}$ See Klein, supra note 12 , at para. 1444 (with regard to the connection between the interpretation of $\$ 31$ FCCA and the constitutional function of the FCC as an institution).

${ }^{19}$ This would also contradict consistent case law: BVerfG, Jun. 10, 1975, docket number 2 BvR 1018/74, 40 BVERFGE 88, 94; BVerfG, Jun. 30, 1976, docket number 2 BvR 164/76, 42 BVERFGE 243, 249 et seq.; BVerfG, May 6, 1986, docket number 1 BvR 677/84, 72 BVERFGE 119, 121.
} 
CJEU", ${ }^{20}$ the First Senate offers to seek. At its heart, the First Senate relies on differentiating between an idea of interpretation ${ }^{21}$ and an idea of application ${ }^{22}$ of EU fundamental rights. The First Senate acknowledges, no surprise here, that the CJEU has the "final authority for interpreting EU law". ${ }^{23}$ The "right application" 24 of EU fundamental rights is, however, what the First Senate claims authority for. The First Senate promises to review whether the challenged decisions of ordinary courts "sufficiently give effect" 25 to the EU fundamental rights and "reflect the required balancing of conflicting rights" 26 with a "tenable outcome"27.

If "interpretation of fundamental rights" was indeed different from "application of fundamental rights", this mode of cooperation could be seen as a flash of genius. And, admittedly, in every rumor there is a little bit of truth. From a typical lower court's perspective, the decisions of higher courts, for instance regarding the FCC or the Federal Court of Justice (Bundesgerichtshof), often seem more general, more abstract and definitely less concrete. Higher courts decide some questions, some of the time. But, as experiences teaches, lower courts still have to decide additional questions afterwards, while applying and implementing the earlier higher court's decisions. The same lower courts' experience goes for the preliminary ruling pursuant to Art. 267 TFEU: The $\mathrm{CJEU}$ answers questions concerning the interpretation of the treaties, but lower court normally still have generic "application"-work to do.

But the seemingly qualitative difference between (higher courts') "interpretation" and (lower courts') "application" is a fallacy. The crucial factor is not the court's task (interpretation or application), but the point in time (must some other court apply the decision or is this decision final?). Looking backwards in the chain of events, earlier decisions seem more general, later decisions seem more concrete, because one can only append what is missing - and the rule of law normally contends against failure to consider existing decisions. But that has nothing to do with earlier decisions being "interpretations" as such and later decisions being "applications" as such.

Thus, the First Senate's concept of cooperation collapses. One does not simply divide and conquer the undividable: There is no question of "right application" 28 of EU fundamental rights that cannot turn into a question of "interpretation of fundamental rights". If the First Senate ever ${ }^{29}$ reverses a court decision on the basis of lack of "right application" 30 of EU fundamental rights and remands the matter to a competent court (for instance, the Federal Court of Justice), this very court might be tempted to initiate a preliminary ruling pursuant to Art. 267 TFEU, referring to the CJEU a question framed as follows: "Is the scope of ( . . . allegedly affected EU fundamental right) to be interpreted to the effect that it is impossible to apply these provisions in a way that a court (... allegedly "wrong" application)?"

On closer examination, there are no reasons for not asking the question and no reasons for not framing these "questions of wrong application" as "questions of right interpretation". Furthermore, there are incentives to do so: the principle, enshrined in the Basic law, of safeguarding the unity and coherence of Union law would be better protected, if the CJEU could prevent some reading of EU fundamental rights as "Germany only". Eventually, it does not go without notice, that (confident) Federal courts, whose decisions are reversed by the FCC, might remain

\footnotetext{
${ }^{20}$ BVerfG, Nov. 6, 2019, docket number 1 BvR 276/17 - Right to be forgotten II, para. 68 et seq.

${ }^{21}$ BVerfG, Nov. 6, 2019, docket number 1 BvR 276/17 - Right to be forgotten II, para. 69.

${ }^{22}$ BVerfG, Nov. 6, 2019, docket number 1 BvR 276/17 - Right to be forgotten II, para. 69.

${ }^{23}$ BVerfG, Nov. 6, 2019, docket number 1 BvR 276/17 - Right to be forgotten II, para. 64, 69, 90.

${ }^{24}$ BVerfG, Nov. 6, 2019, docket number 1 BvR 276/17 - Right to be forgotten II, para. 69.

${ }^{25}$ BVerfG, Nov. 6, 2019, docket number 1 BvR 276/17 - Right to be forgotten II, para. 111.

${ }^{26}$ BVerfG, Nov. 6, 2019, docket number 1 BvR 276/17 - Right to be forgotten II, para. 106 et seq.

${ }^{27}$ BVerfG, Nov. 6, 2019, docket number 1 BvR 276/17 - Right to be forgotten II, para. 111.

${ }^{28}$ BVerfG, Nov. 6, 2019, docket number 1 BvR 276/17 - Right to be forgotten II, para. 69.

${ }^{29}$ In the specific case at hand, establishing the novel jurisdiction, the constitutional complaint was admissible but unsuccessful on the merits. The FCC did not reverse the decision.

${ }^{30}$ BVerfG, Nov. 6, 2019, docket number 1 BvR 276/17 - Right to be forgotten II, para. 69.
} 
deeply convinced of their "right" application and might therefore tend to protect the rule of law by referring to the CJEU.

\section{E. Facing Hobson's Choice?}

The First Senate conveys the impression that the institution was faced with the choice of inventing at least some novel kind of review on the basis of EU fundamental rights or losing institutional influence on domestic application of the ever-growing legislation that is fully harmonized under EU law. The Court frames the perceived institutional constraints as a Hobson's choice: Solely "by incorporating the fundamental rights of the European Union into its standard of review, the Federal Constitutional Court thus discharges its responsibility with respect to European integration" 31 - an institutional responsibility, the First Senate apparently assumes, having been left out in the cold and being dodged otherwise. In addition to these emphasized institutional constraints the Court even doubles down on indicating a Hobson's choice: "What is decisive here", the First Senate explains, "is that under current EU law there would otherwise be a gap in protection regarding the application of EU fundamental rights by the ordinary courts" 32 - so at least individuals without direct access to the CJEU to assert a violation of EU fundamental rights in such cases, are prospectively better off, the First Senate connotes; any filling of a perceived "gap" has the edge over the untreated "gap", the FCC implicitly suggests.

However, with the tedious constitutional status of the novel jurisdiction left entirely undiscussed by the First Senate, it is dangerous to rely on the purported Hobson's choice. What degree of "responsibility with respect to European integration"33 the First Senate can normatively discharge, depends deeply on the constitutional status of the novel jurisdiction, as well as on the question whether individuals effectively benefit from the protection of their fundamental rights. Measuring "responsibility ${ }^{34}$ progress" or "protection ${ }^{35}$ of fundamental rights progress" by number of First Senate orders is like measuring aircraft progress by weight. "We badly need it" is not an conclusive argument for constitutional courts, "most people in the room liked it" is not a sufficient reason for justices and - above all - "the court can implement it" is a necessary, but not sufficient reason for constitutional courts to accept a novel jurisdiction.

The First Senate delivering more judgements is neither always nor by default a gain. It would only be an asset, if these judgements carried something through - be it "responsibility with regard to European integration" 36 or "protection of fundamental rights" 37 . And with the FCC, as mentioned earlier, being confined to reversing unconstitutional court decisions and remanding the matters to competent courts, it is hard to take measure of both aspects without clarifying the legal status of the novel jurisdiction. The ailing status of the novel jurisdiction even threatens the institution with adding insult to injury: Any non-binding or merely provisionally enforceable jurisdiction falling short of safeguarding the unity and coherence of Union law cripples both functions constitutional complaints traditionally fulfill, ${ }^{38}$ as an extraordinary remedy admitted for decision by the FCC, if it has "general constitutional significance", or if this appears necessary

\footnotetext{
${ }^{31}$ BVerfG, Nov. 6, 2019, docket number 1 BvR 276/17 - Right to be forgotten II, para. 53.

${ }^{32}$ BVerfG, Nov. 6, 2019, docket number 1 BvR 276/17 - Right to be forgotten II, para. 60, 61.

${ }^{33}$ BVerfG, Nov. 6, 2019, docket number 1 BvR 276/17 - Right to be forgotten II, para. 53, 55, 67; see in particular Headnote no. 1 to the order.

${ }^{34}$ BVerfG, Nov. 6, 2019, docket number 1 BvR 276/17 - Right to be forgotten II, para. 53, 55, 67; see in particular Headnote no. 1 to the order.

${ }^{35}$ BVerfG, Nov. 6, 2019, docket number 1 BvR 276/17 - Right to be forgotten II, para. 59 et seq.

${ }^{36}$ BVerfG, Nov. 6, 2019, docket number 1 BvR 276/17 - Right to be forgotten II, para. 53, 55, 67; see in particular Headnote no. 1 to the order.

${ }^{37}$ BVerfG, Nov. 6, 2019, docket number 1 BvR 276/17 - Right to be forgotten II, para. 59 et seq.

${ }^{38}$ BVerfG, Jun. 7, 1977, docket number 1 BvR 226/74, 45 BVerfGE 63, 74; BVerfG, Feb. 28, 1989, docket number 1 BvR 1291/85, 79 BVERfGE 365, 367; BVerfG, Apr. 12, 2005, docket number 1 BvR 1027/02, 113 BVerfGE 29, 47.
} 
in order to "enforce" the complainant's own rights under the Constitution. ${ }^{39}$ Any kind of novel jurisdiction without delivering on "general significance" 40 or falling short of at least "enforcing the complainant's rights" ${ }^{\prime 1}$ undermines established expectations set by the (traditional ${ }^{42}$ ) constitutional complaint.

The First Senate has nothing to gain from non-binding or provisional "general significance" 43 . And more importantly, it has nothing to gain from embarking on non-enforceable ${ }^{44}$ constitutional complaints.

\section{F. What is the Use of Consistency without Finality?}

If the constitutional status of the novel jurisdiction covered any binding-effect at all, and that is a big if, ${ }^{45}$ the FCC still would not safeguard the unity and coherence of Union law. Leaving aside the fact that the First Senate is confined to reversing and remanding (unable to enforce anything directly), no beneficial effect on legal certainty ${ }^{46}$ grows apparent.

Any binding-effect of the novel jurisdiction only provides for consistency without finality: Since even if German courts had to constitutionally observe and apply EU fundamental rights within the limits set by the FCC's novel jurisdiction, they could still initiate preliminary rulings pursuant to Art. 267 TFEU. Thus, it appears that finality is no trait the novel jurisdiction could have inherited anyhow (in stark contrast to plain old constitutional complaints).

And to venture further into the question of potential beneficial effects on legal certainty: Even if anyone welcomed this novel kind of consistency without finality (virtually appreciating "provisional consistency"), this oddish consistency would still be a localized consistency, i.e. in German courts only. What concept of "legal certainty" could possibly derive benefit from German courts being constitutionally obliged to create some version of EU fundamental rights that complies with the FCC's jurisdiction?

Considering the First Senate's unspectacular promise of not deviating from binding case law developed by the CJEU, ${ }^{47}$ the novel jurisdiction can only flourish within the established standards of EU fundamental rights. The First Senate is poised to establish "First Senate"-standards within the "CJEU"-standards. This foreshadows over-specific "First Senate"-standards within more general "CJEU"-standards and raises the question of whether (a) any complainant, or (b) unity and coherence of EU law, or (c) German constitutional law principles could possibly demand, or even appreciate, these Russian doll-like "standards within standards"?

From the potential complainant's perspective, the envisaged "standards within standards" seem neither better nor worse than the already established "CJEU"-standards, but different and obviously provisional. The novel jurisdiction potentially prolongs certain lawsuits by adding one extra level of indirection (the First Senate being confined to reversing and remanding, without enforcing anything directly), which is per se no enhancement.

Unity and coherence of Union law have literally nothing to gain from EU fundamental rights standards of review, which are prospectively more specific throughout Germany than the more general standards for the European rest of us. Were unity and coherence of Union law truly

\footnotetext{
${ }^{39}$ See $\$ 93$ a FCCA.

${ }^{40} \$ 93 \mathrm{a}$ (2) lit. a FCCA; BVerfG, Feb. 8, 1994, docket number 1 BvR 1693/92, 90 BVERFGE 22, 24 seq.; BVerfG, Oct. 7, 2003, docket number 1 BvR 1712/01, 108 BVERFGE 370, 386.

${ }^{41} \S 93$ a (2) lit. b FCCA; BVerfG, Feb. 8, 1994, docket number 1 BvR 1693/92, 90 BVERFGE 22, 25 seq.

${ }^{42}$ See B.

${ }^{43}$ Repugnant to $\$ 93 a(2)$ lit. a FCCA.

${ }^{44}$ Repugnant to $\$ 93 \mathrm{a}(2)$ lit. b FCCA.

${ }^{45}$ See C.

${ }^{46}$ See BVerfG, May 21, 1974, docket number 1 BvL 22/71, 37 BVerfGE 217, 262 et seq.; BVerfG, Mar. 22, 1990, docket number 2 BvL 1/86, 81 BVERFGE 363, 384,) (with regard to legal certainty); Klein, supra note 12, at para. 1423.

${ }^{47}$ BVerfG, Nov. 6, 2019, docket number 1 BvR 276/17 - Right to be forgotten II, para. 69.
} 
strengthened by the First Senate dwelling on thoughts like: "The fundamental rights of both the Basic Law and the Charter are not limited to protecting citizens vis-à-vis the state, but also afford protection in disputes under private law."? ${ }^{48}$ Maybe foundational issues like the question of "guarantees in disputes under private law" were better be clarified coherently rather than "Germany only".

A corollary to this last observation is the duty to take applicable constitutional principles seriously, namely the Basic Law's obligation incumbent on the FCC to "safeguard the unity and coherence of Union law". This constitutional principle has already crystallized out in past judgements of the Second Senate. ${ }^{49}$ The First Senate might be inclined to take up this thread, as soon as clarifications of the opaque status of the novel jurisdiction are pending.

\footnotetext{
${ }^{48}$ BVerfG, Nov. 6, 2019, docket number 1 BvR 276/17 - Right to be forgotten II, para. 96-97; see in particular Headnote no. 4 to the order.

${ }^{49}$ See BVerfG, Jun. 30, 2009, docket number 2 BvR 1010/08, 123 BVerfGE 267 (354) - Lissabon; BVerfG, Jul. 6, 2010, docket number 2 BvR 2661/06, 126 BVerfGE 286, 302-303 - Honeywell; Karsten Schneider, $\$ 1$, in BUNDESVERFASSUNGSGERICHTSGESETZ para. 159 (Christian Burkiczak, Franz-Wilhelm Dollinger \& Frank Schorkopf eds., 2015).
} 